\title{
Physiologie de la Barrière Sang-Testicule
}

\author{
B.P. SETCHELL
}

\author{
Pediatric Endocrinology Unit, Karolinska Hospital, Stockholm, Suède et \\ Department of Anatomical Sciences, University of Adelaide, Australie
}

\begin{abstract}
RÉSUMÉ
Des preuves de l'existence d'une barrière entre la lumière des tubes séminifères et le sang sont représentées par: la coloration inégale des testicules après injection de certains colorants, la distribution des substances radioactives dans le testicule, la composition des fluides du rete testis et de la lumière des tubes, la vitesse de pénétration de différentes substances dans ces fluides, et la présence de jonctions spécialisées entre les cellules de Sertoli qui bloquent la pénétration du lanthanum et d'autres marqueurs opaques aux électrons dans les tubules. Cette barrière se développe au moment de la puberté. Cependant, les cellules endothéliales du testicule ont des caractéristiques qui sont retrouvées dans les cellules endothéliales du cerveau qui forment la barrière sang-cerveau. Le tissu péritubulaire possède aussi un système spécifique pour le transport de l'urée, et ces deux tissus peuvent aussi réguler l'entrée des substances dans le testicule. La barrière reste effective dans certaines circonstances dans lesquelles la spermatogenèse est perturbée, mais la barrière est moins effective pendant la phase de régression testiculaire chez les espèces à reproduction saisonnière. Il existe aussi des traitements qui rompent la barrière en perturbant la spermatogenèse. Il faut que les spermatogonies injectées dans le rete passent à travers la barrière Sertolienne pour rétablir la spermatogenèse dans les testicules infertiles, mais les cellules leucémiques injectées dans le rete peuvent aussi passer de la lumière dans l'interstitium où une récidive de la maladie peut survenir.
\end{abstract}

Mots Clés : Barrière, transport, testicule, Sertoli, spermatogenèse, leucémie
Les preuves de l'existence d'une barrière ou de barrières entre le sang et les tubules séminifêres sont apparues il y a presque cent ans. Un dessin de Goldmann [11] datant de 1909 représente un testicule de rat dans lequel on a injecté de la teinture bleue pyrrol. On peut voir que les tubes séminifêres ne sont pas colorés, mais le tissu interstitiel montre une forte coloration bleue. Plus récemment, il y a eu d'autres études de la distribution de substances radioactives mesurée par autoradiographie, et on a dit que quelques unes étaient exclues des tubes séminifêres [37]. On a pu aussi mesurer l'espace ou volume de distribution, que l'on exprime en microlitres par gramme, d'un indicateur radioactif, comme le Cr-EDTA par exemple, espace qui représente normalement $60 \% \mathrm{du}$ volume du tissu interstitiel quand il est estimé par morphométrie [40]. Ce chiffre est augmenté si la barrière est rompue [41].

Des observations identiques ont été faites sur le cerveau, et l'on a parlé d'une barrière sang-cerveau dans de nombreuses publications depuis longtemps, alors que l'on a parlé d'une barrière sang-testicule qu'à partir des travaux de Kormano en 1967 [17], qui montrait que des colorants étaient exclus des tubes séminifères de rats adultes, mais pas de ceux de rats avant la puberté. Le light green et l'acriflavine sont exclus des tubes de rats

Correspondance : B.P. Setchell, Pediatric Endocrinology Unit, Karolinska Hospital, Stockholm, Suède

Communication au XVIIème Congrès de la SALF, 7-8 décembre 2000, Bordeaux 
adultes, mais ils ne le sont pas des tubes avant la puberté, chez les rats qui ont moins de 20 jours. Les vaisseaux, le rete et l'épididyme sont toujours colorés. De même, le cerveau est un peu coloré chez les rats les plus jeunes ; il existe aussi une diminution de la coloration du tissu interstitiel, et les capillaires développent un taux élevé de phosphatase alcaline.

Durant la même période, nous avions commencé, Geoffrey Waites et moi-même, à recueillir chez le bélier le fluide du rete testis $[44,45]$ et chez le rat les fluides du rete testis et de la lumière des tubes séminifêres [43]. Nous avons remarqué que les deux fluides étaient bien différents du plasma sanguin. Il y a des différences importantes de concentrations des ions, et ces différences sont encore plus grandes pour certaines substances organiques [38]. Ces différences n'existeraient pas si les substances passaient facilement à travers la paroi des tubules ou du rete. Nous avons ensuite étudié la pénétration d'indicateurs depuis le sang jusque dans le fluide du rete testis $[39,46]$ ou des tubes séminifères. La pénétration est plus rapide pour l'eau tritiée et les substances lipophiles, alors que les grosses molécules hydrophiles, comme l'EDTA, et les protéines, sont presque exclues [37, 46]. Cependant, quelques peptides de petite taille peuvent entrer dans les tubes [1].

Comment une substance peut-elle aller du sang à la lumière d'un tube séminifère ? Il lui faut passer à travers les cellules endothéliales des vaisseaux, puis à travers le tissu péritubulaire, et enfin entre ou à travers les cellules de Sertoli. Les jonctions particulières entre les faces adjacentes de ces cellules [24] empêchent l'entrée dans le tube entre les cellules de Sertoli de substances hydrophiles et de marqueurs opaques aux électrons, comme le lanthanum [5, 29]. A ces jonctions s'associent des protéines telles que les connexines, l'actine, la vinculine et l'espine, protéines qui sont aussi retrouvées dans les spécialisations ectoplasmiques présentes entre cellules de Sertoli et spermatides [27, 31].

Mais il ne nous faut pas oublier les cellules endothéliales et le tissu péritubulaire. Les cellules du tissu péritubulaire ont un système spécifique dans le testicule pour le transport de l'urée, comme cela a été montré par Fenton et al. [8]. Les cellules endothéliales possèdent un système spécifique pour le transport de la leucine [2]. Holash et al. [13] ont montré que les cellules endothéliales sont aussi équipées d'un système de transport pour le glucose (GLUT-1) et la glycoprotéine P, produit du gène de multi-résistance aux médicaments, deux protéines que l'on croyait spécifiques des cellules endothéliales du cerveau. Les souris déficientes en P-glycoproteine accumulent certains médicaments dans leurs testicules [33], et les testicules des souris qui manquent la protéine apparenté $m r p 1$, qui se trouve dans les cellules de Sertoli, sont plus sensibles aux dégâts par l'etoposide phosphate [48]. Holash et al. [13] ont aussi montré que les cellules leydigiennes, qui sont très près des cellules endothéliales, possèdent aussi la protéine S-100 et l'enzyme glutamine synthétase qui sont caractéristiques des astrocytes, cellules du cerveau qui confèrent aux cellules endothéliales cérébrales leurs caractéristiques spécifiques. Plus récemment, à Adélaïde, Mounir Ghabriel [communication personnelle] a montré que les cellules endothéliales du testicule ont aussi l'antigène de la barrière endothéliale (EBA) que l'on croyait auparavant spécifique des cellules endothéliales du cerveau [19].

On a suggéré que les hormones peptidiques, comme la LH, n'atteignaient pas facilement les cellules de Leydig, parce qu'elles ne passaient pas facilement à travers les cellules endothéliales [35]. Si on contrôle le taux de LH dans le sang et dans la lymphe testiculaire de béliers auxquels on a injecté du LHRH, on peut voir que le taux de $\mathrm{LH}$ est bien et rapidement élevé dans le sang, mais très peu est très lentement élevé dans la lymphe. Ghinea et ses collaborateurs [10] ont suggéré que la LH était transportée à travers les cellules endothéliales par endocytose, mais il est possible que les cellules endothéliales soient impliquées dans l'action de la LH lors de la stimulation de la sécrétion de testostérone.

Comme nous l'avons déjà dit, la barrière sangtesticule s'établit au moment de la puberté, puis elle va rester effective dans certaines circonstances dans lesquelles la spermatogenèse est perturbée $[12,16]$. Cependant, chez les ani- 
maux à reproduction saisonnière, comme par exemple le vison et le viscache, on a montré que la barrière devenait moins effective pendant la régression testiculaire saisonnière [23, 27]. Il existe aussi des traitements qui rompent la barrière. Après les traitements qui désorganisent les microtubules dans les cellules Sertoliennes [7, 16, 30, 47], la barrière est rompue et la spermatogenèse s'arrête. Il en est de même après la ligature des canaux efférents [40] ou l'injection de sels de cadmium [36], chez les rats très vieux. [21] et lors de carence en Vitamine A [14]. Chez l'homme, on dispose de deux publications. L'une [22] indique que la barrière au lanthanum n'existe pas dans les testicules avec arrêt de maturation de la spermatogenèse ou en cas d'hypospermatogenèse irrégulière ; mais cette barrière existe toujours lors d'une aplasie des cellules germinales. L'autre [4] indique que la barrière n'existe pas si les cellules germinales sont absentes, mais qu'elle est normale en cas d'infertilité avec azoospermie idiopathique ou oligospermie.

Il faut prendre en compte la barrière dans le processus des greffes de spermatogonies dans le testicule adulte, comme l'ont fait Brinster et al. [25, 26] aux Etats Unis et Stephan Schlatt [34] en Allemagne. Les spermatogonies passent normalement du centre des tubules séminifêres entre les cellules de Sertoli chez le foetus, et vont s'établir contre la paroi du tube. Ceci se produit normalement avant l'établissement des jonctions entre les cellules de Sertoli. Chez l'adulte, les cellules germinales en développement passent entre les cellules de Sertoli par la formation d'une nouvelle jonction en amont des cellules germinales, puis par l'ouverture des anciennes jonctions pour permettre le passage des cellules germinales du compartiment basal au compartiment adluminal $[6,32]$. Si l'on réalise une greffe de spermatogonies dans la lumière ou dans le rete, comment ces cellules peuvent-elles arriver contre la paroi du tube séminifêre ? On ne le sait pas, mais on a fait ces expériences chez les souris adultes d'une souche infertile ou chez celles traitées avec du busulfan pour arrêter la spermatogenèse. On ne sait pas si la barrière est effective chez ces animaux, mais chez les souris Tfm et $S x r$, la barrière n'est pas effective, bien qu'elle soit normale chez les animaux des souches infertiles $M o 7 Y, G y / Y$ et $t^{6} t^{w 1}$ [9]. La sécrétion de fluide, qui a besoin d'une barrière effective, est même augmentée chez les rats adultes après busulfan [18]. Mais chez les rats adultes traités avant la naissance avec busulfan, le fluide de la lumière des tubes présente un taux réduit de potassium, comme le plasma sanguin [20,42], ce qui suggère que la barrière n'est plus effective chez eux, et la barrière au lanthanum n'existe pas [3].

On sait que quelques autres cellules peuvent passer entre les cellules de Sertoli de la lumière au tissu interstitiel. Jahnukainen et al. ont montré [15] que les cellules leucémiques pouvaient passer du tube séminifêre dans l'interstitium. Si on fait une greffe de cellules de testicule de rat leucémique, la maladie se développe dans les 14 jours suivants dans l'interstitium chez les rats qui reçoivent la greffe soit dans le rete soit dans l'interstitium. Dans les testicules de rats receveurs, qui ont été traités par busulfan pour arrêter leur propre spermatogenèse, on peut voir beaucoup de cellules leucémiques entre les tubes séminifères, mais aucune dans les tubes, bien que les cellules aient été injectées dans le rete. Une telle récurrence arrive quand on greffe 20 cellules leucémiques d'un ganglion lymphatique d'un rat leucémique mélangées à 1,5 millions de cellules d'un testicule de rat normal. Ces résultats impliquent une grande prudence avant de réaliser des greffes dans les testicules pour traiter l'infertilité des hommes guéris de leucémie.

En conclusion, on peut dire que la barrière sang-testicule est plus compliquée qu'on ne l'a cru, que les cellules endothéliales sont peutêtre importantes, que la barrière est importante pour la spermatogenèse normale ; toutefois, certaines cellules, à la fois les spermatogonies mais aussi les cellules leucémiques, peuvent traverser la barrière entre les cellules de Sertoli et passer ainsi de la lumière dans le tissu interstitiel où elles peuvent produire une récidive de la maladie en cas de traitement de l'infertilité par greffe. 


\section{RÉFÉRENCES}

1. BANKS W.A., McLAY R.N., KASTIN A.J., SARMIENTO U., SCULLY S. : Passage of leptin across the blood testis barrier. Am. J. Physiol., 1999, 276 : E1099E1104.

2. BUSTAMANTE J.C., SETCHELL B.P. : The uptake of amino acids, in particular leucine, by isolated perfused testes of rats. J. Androl., 2000, 21 : 452-463.

3. CAVICCHIA J.C., SACERDOTE F.L. : Correlation between blood-testis barrier development and onset of the first spermatogenic wave in normal and in Busulfan-treated rats: a lanthanum and freeze-fracture study. Anat. Rec., 1991, $230: 361-368$.

4. CAVICCHIA J.C., SACERDOTE F.L., ORTIZ L. : The human blood-testis barrier in impaired spermatogenesis. Ultrastruct. Pathol., 1996, 20 : 211-218.

5. DYM M., FAWCETT D.M. : The blood-testis barrier in the rat and the physiological compartmentation of the seminiferous epithelium. Biol. Reprod., 1970, 3 : 308326.

6. DYM M., CAVICCHIA J.C. : Further observations on the blood-testis barrier in monkeys. Biol. Reprod., $1977,17: 390-403$.

7. ENG F., WIEBE J.P., ALIMA L.H. : Long-term alterations in the permeability of the blood-testis barrier following a single intratesticular injection of dilute aqueous glycerol. J. Androl., 1994, 15 : 311-317.

8. FENTON R.A., HOWORTH A., COOPER G.J., MECCARIELLO R., MORIS I.D. : Molecular characterization of a novel UT-A urea transporter isoform (UT-A5) in testis. Amer. J. Physiol., 2000, 279 : C1425-C1431.

9. FRITZ I.B., LYON M.F., SETCHELL B.P. : Evidence for a defective seminiferous tubule barrier in testes of Tfm and Sxr mice. J. Reprod. Fertil., 1983, 67 : 359363.

10. GHINEA N., HAI M.T.V., GROYER-PICARD M.T., MILGROM E. : How protein hormones reach their target cells. Receptor mediated transcytosis of hCG through endothelial cells. J. Cell Biol., 1994, 125 : 87 97.

11. GOLDMANN E.E. : Die äussere und innere Sekretion des gesunden und kranken Organismus im Lichte der "vitalen Färbung". Beitr. Klin. Chirug., 1909, 64 : 192265.

12. HAGENÄS L., PLÖEN L., RITZEN E.M., EKWALL H. : Blood-testis barrier: Maintained function of interSertoli cell junctions in experimental cryptorchidism in the rat, as judged by a simple lanthanum-immersion technique. Andrologia, 1977, 9 : 3-7.

13. HOLASH J.A., HARIK S.I., PERRY G., STEWART P.A. Barrier properties of testis microvessels. Proc. Nat. Acad. Sci. USA., 1993, 90 : 11069-11073.

14. HUANG H.F.S., YANG C.S., MEYENHOFER M.,
GOULD S., BOCCABELLA A.V. : Disruption of sustentacular (Sertoli) cell tight junctions and regression of spermatogenesis in vitamin-A-deficient rats. Acta Anat., 1988, 133 : 10-15.

15. JAHNUKAINEN K., HOU M., PETERSEN C., SETCHELL B., SÖDER O. : Intratesticular transplantation of testicular germ cell from leukemic rats causes transmission of leukemia. Cancer Res. 2001 : in press.

16. JOHNSON K.J., HALL E.S., BOEKELHEIDE K. : 2,5-Hexanedione exposure alters rat Sertoli cell cytoskeleton 1. Microtubules and seminiferous tubule fluid secretion. Toxicol. Appl. Pharmacol., 1991, 111 : 432442.

17. KORMANO M. : Dye permeability and alkaline phosphatase activity of testicular capillaries in the postnatal rat. Histochemie, 1967, $9: 327-338$.

18. LAPORTE P, GILLE'T J. : Influence de la spermatogenese sur la secretion du fluide testiculaire chez le rat adulte. C. R. Acad. Sci. Paris, 1975, $281: 1397-$ 1400.

19. LAWRENSON J.G., GHABRIEL M.N., REID A.R., GAJREE T.N., ALLT G. Differential expression of an endothelial barrier antigen between the CNS and PNS. J. Anat., 1995, $186:$ 217-221.

20. LEVINE N., MARSH D.J. : Micropuncture study of the fluid composition of 'Sertoli cell-only' tubules in rats. J. Reprod. Fertil., 1975, $43: 547-549$.

21. LEVY S., SERRE V., HERMO L., ROBAIRE B. : The effects of aging on the seminiferous epithelium and the blood-testis barrier of the Brown Norway rat. J. Androl., 1999, 20 : 356-365.

22. MEYER J.M., MEZRAHID P., VIGNON F., CHABRIER G., REISS D., RUMPLER Y. : Sertoli cell barrier dysfunction and spermatogenetic cycle breakdown in the human testis: a lanthanum study. Int. J. Androl., 1996, 19 : 190-198.

23. MORALES A., CAVICCHIA J.C. : Seasonal changes of the blood-testis barrier in viscacha: a freeze-fracture and lanthanum study. Anat. Rec., 1993, 236 : 459464.

24. NICANDER L. : An electon microscopical study of cell contacts in the seminiferous tubules of some mammals. Z. Zellforsch., 1967, $83:$ 375-397.

25. OGAWA T., DOBRINSKI I., BRINSTER R.L. : Recipient preparation is critical for spermatogonial transplantation in the rat. Tissue Cell, 1999, 31 : 461472.

26. OGAWA T., DOBRINSKI I., AVARBOCK M.R., BRINSTER R.L. : Transplantation of male germ line stem cells restores fertility in infertile mice. Nature Medicine, 2000, $6: 29-34$.

27. O'DONNELL L., STANTON P.G., BARTLES J.R., ROBERTSON D.M. : Sertoli cell ectoplasmic specializations in the seminiferous epithelium of the testosterone-suppressed adult rat. Biol. Reprod., 2000, 63 : 99-108. 
28. PELLETIER RM. : Cyclic formation and decay of the blood-testis barrier in the mink. Am. J. Anat., 1986, 175 : 91-117.

29. PLÖEN L., SETCHELL B.P. : Blood-testis barriers revisited: a hommage to Lennart Nicander. Int. J. Androl., 1992, $15:$ 1-4.

30. POGACH L.M., LEE Y., GOULD S., GIGLIO W., MEYENHOFER M., HUANG H.F.S. Characterization of cis-platinum Sertoli cell dysfunction in rodents. Toxicol. Appl. Pharmacol., 1989, 98 : 350-361.

31. RISLEY M.S., TAN I.P., ROY C., SAEZ J.C. : Cell-, age- and stage-dependent distribution of connexin 43 gap junctions in testes. J. Cell Sci., 1991, 103 : 81-96.

32. RUSSELL L. : Movement of spermatocytes from the basal to the adluminal compartment of the rat testis. Am. J. Anat., 1977, 148 : 313-328.

33. SCHINKEL A.H., WAGENAAR E., MOL CAAM., VAN DEEMTER L. : P-Glycoprotein in the bloodbrain barrier of mice influence the brain penetration and pharmacological activity of many drugs. J. Clin. Invest., 1996, $97: 2517-2524$.

34. SCHLATT S. : Prospects and problems for germ cell transplantation in the male. Int. J. Androl., 1999, 22: 13-18.

35. SETCHELL B.P. : Possible physiological bases for contraceptive techniques in the male. Hum. Reprod., 1994, 9 : 1081-1087.

36. SETCHELL B.P., WAITES G.M.H. : Changes in the permeability of testicular capillaries and of the "blood-testis barrier" after injection of cadmium chloride in the rat. J. Endocrinol., 1970, 41 : 81-86.

37. SETCHELL B.P., WAITES G.M.H. : The blood-testis barrier. In : Hamilton DW., Greep RO. eds. Handbook of Physiology, Section 7, Endocrinology, Volume V, Male Reproductive System. Washington D.C., American Physiological Society, 1975 : 143-172.

38. SETCHELL B.P., SCOTT T.W., VOGLMAYR J.K., WAITES G.M.H. : Characteristics of testicular spermatozoa and the fluid which transports them into the epididymis. Biol. Reprod., 1969, (Suppl 1) : 40-66.

39. SETCHELL B.P., VOGLMAYR J.K., WAITES G.M.H. : A blood-testis barrier restricting passage from blood into rete testis fluid but not into lymph. J. Physiol., $1969,200: 73-85$.

40. SETCHELL B.P., TAO L., ZUPP J.L. : The penetration of chromium-EDTA from blood plasma into various compartments of rat testes, as an indicator of function of the blood-testis barrier, following exposure of the testes to heat. J. Reprod. Fertil., 1996, 106 : 125-133.

41. TAO L., ZUPP J.L., SETCHELL B.P. : Effect of efferent duct ligation on the function of the blood-testis barrier. J. Reprod. Fertil., 2000, 120 : 13-18.

42. TUCK R.R., quoted by SETCHELL B.P., DAVIS R.V., GLADWELL R.T., et al. : The movement of fluid in the seminiferous tubules and rete testis. Ann. Biol. Anim. Bioch. Biophys., 1978, 18 : 623-632.

43. TUCK R.R., SETCHELL B.P., WAITES G.M.H., YOUNG J.A. : The composition of fluid collected by micropuncture and catheterization from the seminiferous tubules and rete testis of rats. Pflugers Archiv, 1970, $318: 225-243$.

44. VOGLMAYR J.K., WAITES G.M.H., SETCHELL B.P. : Studies on spermatozoa and fluid collected directly from the testis of the conscious ram. Nature (London), $1966,210: 861-863$.

45. VOGLMAYR J.K., SCOTT T.W., SETCHELL B.P., WAITES G.M.H. : Metabolism of testicular spermatozoa and characteristics of testicular fluid collected from the conscious ram. J. Reprod. Fertil., 1967, 14 : 87-99.

46. WAITES G.M.H. : Fluid secretion. In : Johnson A.D., Gomes W.R. eds. The Testis, Vol IV, New York, Academic Press, 91-123.

47. WEBER JE., TURNER TT., TUNG KSK., RUSSELL LD. : Effects of cytochalasin D on the integrity of the Sertoli cell (blood-testis) barrier. Am. J. Anat., 1988, $182: 130-147$.

48. WIJNHOLDS J., SCHEFFER G.L., VAN DER VALK M., VAN DER VALK P., BEIJNEN J.H., SCHEPER R.J., BORST P. : Multidrug resistance protein 1 protects the oropharyngeal mucosal layer and the testicular tubules against drug-induced damage. J. Exp. Med., 1998, 188 : 797-808.

\section{ABSTRACT}

The Physiology of the Blood-Testis Barrier.

B.P. SETCHELL

There is evidence for the existence of a barrier between the blood and the lumina of the seminiferous tubules, from the uneven coloration of the testis after injection of some dyes, from the distribution of some radioactive markers, from the composition of the fluids from the rete testis and the seminiferous tubules, from the rate of penetration of various substances into these fluids, and from the presence of specialized junctions between the Sertoli cells, which block the penetration of lanthanum and other electron-opaque markers into the tubules. This barrier develops only at the time of puberty. However, the endothelial cells in the testis share certain 
characteristics with the endothelial cells of the brain, which form the blood-brain barrier. Also, the peritubular tissue has a specific transport system for urea, and these two tissues may also regulate the entry of substances into the testis. The barrier remains effective in some circumstances where spermatogenesis is disrupted, but it is less effective outside the breeding season in seasonal breeders. There are also some treatments which break down the barrier and disrupt spermatogenesis. Spermatogonia injected into the rete must pass through the barrier to re-establish spermatogenesis in infertile testes, but leukaemic cells injected into the rete can also pass from the lumen of the tubules into the interstitium, where the disease then recurs.

Key words : Barrier, transport, testis, Sertoli, spermatogenesis, leukemia 